\title{
Special Issue Editorial
}

\section{Andrew Quinn}

Social work professors have been reviewing the fit of technology in education since the 1950s when audiovisual materials were used for training (Shorkey \& Uebel, 2014). Throughout the early to late 1980s, the social work field began to see a push to use Internet technology in the classroom. This led to a gathering of social work educators (the 1998 Information Technologies for Social Work Education and Practice group, hosted by the College of Social Work at the University of South Carolina) interested in using technology for educational purposes. Such gatherings led to an increase in publications debating what courses we should teach, how we should teach them, and how to best use technology to our advantage to reach our students. Now almost 20 years after the first gathering of social work educators for the sole purpose of discussing technology, we are entering our second iteration of the conference (now hosted by Indiana University and the Council on Social Work Education [CSWE], beginning in 2015) and another opportunity for social work professors to gather and discuss the role of technology in social work education.

Technology has changed since the first South Carolina technology conference. Compared to the use of interactive television discussed at the conference by the likes of Petracchi and Patchner (2000, 2001) and Haga and Heitkamp (2000), where a student had to drive to a location to receive real-time education through a television screen, we can now deliver from anywhere to anyone in the world in the convenience of the students' home or workplace (or our home or workplace) using synchronous technologies like Adobe Connect Professional (Quinn, Regan, \& Schoech, 2008) or asynchronous approaches such as virtual role plays delivered through a course management system (Levine, 2013). The ever-changing face of technology has allowed us to become creative in our delivery methods and really offer our content to those at a distance, those who are place bound, or those who do not have reasonable access to a campus for classroom instruction. In fact, according to the CSWE's most current information, over 40 programs offer distance education (CSWE, n.d.). However, regardless of the type of technology used in the delivery, the debate remains: a) What courses can we teach using technology (including practice and field, b) What are the best practices in teaching our courses, c) What are the technology competencies that we should teach our students, and d) How can we best use technology to reach a broader population of students? This special edition of Advances in Social Work includes articles based on presentations at the 2015 Social Work Distance Education Conference hosted by Indiana University and CSWE and offers some insight to the debate.

\section{Articles in this Edition}

This special issue contains seven articles that emerged from presentations made during the conference. One of the challenges in offering distance education is engagement. Two of the articles in this edition focus on engagement, whether it was direct engagement of the student or engagement of faculty who teach in the distance program. First, Rapp-McCall

Andrew Quinn, PhD, LCSW is an Associate Professor, Department of Social Work, University of North Dakota, Grand

Forks, ND 58202

Copyright (C) 2016 Advances in Social Work Vol. 17 No. 1 (Spring 2016), i-iv, DOI: 10.18060/21092 
and Anyikwa focus on which active learning strategies are best used to engage students in an online research methods course and to reduce anxiety while increasing student perceptions of knowledge. These strategies include contact with the professor, synchronous class sessions, and synchronous activities such as games and discussions. Second, Schwartz shares outcomes of interviews with several faculty and adjuncts about their experiences teaching for a large program on the west coast. Her qualitative analysis demonstrated that the respondents appreciated the diversity that distance education offerings bring, although there were some challenges related to community-building among faculty, especially those far from campus and those who only taught part-time, and there were also some challenges building community between students and faculty. For example, not having the ability for informal discussions that typically occur in campus offices and hallways was seen as a hindrance to engagement. However, when synchronous technologies were used along with email communication, Schwartz reports that some faculty felt like their distance teaching experience was no different than the on-campus experience.

This comparison, distance versus campus, was also the focus of several articles in this special edition. Cotton, Faul, and Yankeelov examined differences between distance students and campus students related to demographics and performance variables (cumulative GPA, critical thinking scores, and CSWE Educational Policy and Accreditation [EPAS] competency scores). While they ultimately found subtle differences between campus and distance demographics, there were no significant differences between the two in terms of performance variables. Brown and Park compared students' practice evaluation knowledge and their research self-efficacy, both within and between a campus class and a distance online class. Like Cotton and colleagues, Brown and Park found no differences between the two types of offerings. Next, Forgey and Ortega-Williams examined the much debated question of "Can practice be taught online?" The authors compared a face-to-face and an online generalist practice course on several outcome measures, including but not limited to learning outcomes, student perception of how learning objectives were met, the quality of the learning environment, and teaching strategies. For the most part, no significant differences were seen between the face-to-face and the online sections. These aforementioned demonstrations of no significant differences between face-to-face and distance education offerings adds support to the existing suggestions that we can move our educational practices online without affecting learning outcomes. This, in turn, creates opportunities to move away from the comparison and focus on the types of courses, the pedagogical approaches best suited for distance education, and best practices for the types of technology that can be used in distance education.

While an actual comparison between face-to-face and distance classes was not undertaken, Fitch, Canada, Cary, and Freese offered their thoughts on using technology to conduct online role plays that according to the authors demonstrated there was "no distinguishable time and effort demands associated with the online video conferencing compared to classroom role plays.” The final paper in this special edition comes from Sage and Sage, who describe the results of a survey that asked child welfare workers about the use of social media. While their particular research was not necessarily rooted in a distance education classroom, social media is becoming a presence in education and in the 
profession. In fact, Sage and Sage demonstrated the need for training on proper use of social media in social work. They noticed that very few of their participants received any lengthy training (greater than an hour) in their respective social work programs. Their findings raise questions regarding the proper training on technology competency since technology has become such a substantial part of social work practice.

This special edition concludes with a reflection piece written by Jo Ann Coe Regan, a mentor, co-author, and the Vice President of Education at CSWE. Dr. Regan was involved in the South Carolina conference and is now heavily involved in the Indiana conference. Her piece, which was commissioned for this special edition, reflects back on the early years of technology adoption in social work and offers tribute to Dean Frank Raymond, an innovator and educator, who desired to bring the technology conversation to the forefront. She reminds us that we need educators like Dean Raymond who are willing to engage in conversation about best practices related to technology and social work education. Dr. Regan, in concluding her reflections, also reminds us that conferences and special editions (such as this one) are absolutely necessary to keep the conversation about the use of technology in social work education alive.

\section{Conclusion}

The landscape of social work education is changing, and distance conferences such as the Social Work Distance Education Conference hosted by Indiana University and CSWE allow for conversations to occur. We as social work educators need to continue to research best practices in distance education, so that we can learn which approaches are most efficient to implement and the most effective for instructing distance learning students. In doing so, we need to move beyond comparing classroom to online, asking questions about whether practice can occur online, and move toward some of the upcoming challenges such as virtual field placements. As a social work educator who is invested in the use of technology in education, I encourage us to continue the debate about best practices as it relates to distance education in social work.

We hope to see you April 14-17, 2017 in San Antonio for the 3rd Annual Social Work Distance Education Conference.

Andrew Quinn, PhD

March 2016

\section{References}

Council on Social Work Education. (n.d.). Council on Social Work Education (CSWE)Online and Distance Education.Retrieved from http://cswe.org/Accreditation/Information/OnlineandDistanceEducation.aspx

Haga, M., \& Heitkamp, T. (2000). Bringing social work education to the prairie. Journal of Social Work Education, 36(2), 309-324.

Levine, J. (2013). Teaching groupwork at a distance using an asynchronous online roleplay. Groupwork 23(1), 56-72. doi: http://dx.doi.org/10.1921/1601230104 
Petracchi, H. E., \& Patchner, M. E. (2000). Social work students and their learning environment: A comparison of interactive television, face-to-face instruction, and the traditional classroom. Journal of Social Work Education, 36(2), 335-346.

Petracchi, H. E., \& Patchner, M. E. (2001). A comparison of live instruction and interactive televised teaching: A 2-year assessment of teaching an MSW research methods course. Research on Social Work Practice, 11(1), 108-117. doi: http://dx.doi.org/10.1177/104973150101100107

Quinn, A., Regan, J., \& Schoech, D. (2008). Online synchronous audio and video environments for education, training, and human service delivery: A review of Adobe Connect Professional, Elluminate, and Flash Meeting. Journal of Technology in Human Service, 28(1), 89-104. doi: http://dx.doi.org/10.1300/J017v26n01 07

Shorkey, C. T., \& Uebel, M. (2014). History and development of instructional technology and media in social work education. Journal of Social Work Education, 50(2), 247261. 


\section{SAVE THE DATE \\ APRIL 12-14, 2017 \\ 2017 SWDE CONFERENCE}

San Antonio, Texas

Hilton Palacio del Rio

(Located on the San Antonio River Walk)

\section{SOCIal Committed Relationships}

Community Work Integrity Professional

Conseacting Advocacy Distance

Field Education DIStance

Innovative Education Authentic 总

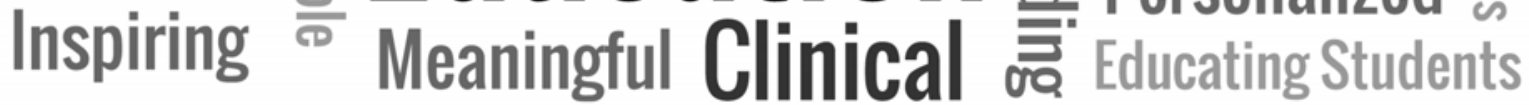

Sponsored by

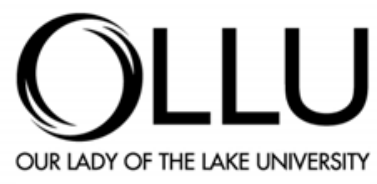

WORDEN SCHOOL

OF SOCIAL SERVICE 